\title{
Synonymy of the yeast genera Moniliella and Trichosporonoides and proposal of Moniliella fonsecae sp. nov. and five new species combinations
}

\section{Correspondence \\ Carlos A. Rosa carlrosa@icb.ufmg.br}

Carlos A. Rosa, ${ }^{1}$ Sasitorn Jindamorakot, ${ }^{2}$ Savitree Limtong, ${ }^{3}$

Takashi Nakase, ${ }^{4}$ Marc-André Lachance, ${ }^{5}$ Abel Fidalgo-Jiménez, 6,7

Heide-Marie Daniel, ${ }^{7}$ Fernando C. Pagnocca, ${ }^{8}$ João Inácio ${ }^{9}$ and Paula B. Morais ${ }^{10}$

\footnotetext{
${ }^{1}$ Departamento de Microbiologia, ICB, CP 486, Universidade Federal de Minas Gerais, Belo Horizonte, MG 31270-901, Brazil

${ }^{2}$ BIOTEC Culture Collection, National Center for Genetic Engineering and Biotechnology (BIOTEC), 113 Paholyothin Road, Klong 1, Klong Luang, Pathumthani 12120, Thailand

${ }^{3}$ Department of Microbiology, Faculty of Science, Kasetsart University, 50 Paholyothin Road, Bangkok 10900, Thailand

${ }^{4}$ NITE Biological Resource Center (NBRC), National Institute of Technology and Evaluation, 2-5-8 Kazusakamatari, Kisaraza, Chiba 292-0818, Japan

${ }^{5}$ Department of Biology, University of Western Ontario, London, ON N6A 5B7, Canada

${ }^{6}$ Instituto de Ecología y Sistemática (IES), Carretera de Varona, km 3 1⁄2 Capdevila, Boyeros, AP8029 CP 10800, Ciudad de la Habana, Cuba

${ }^{7}$ Mycothèque de l'Université catholique de Louvain (MUCL), Member of the Belgian Coordinated Collection of Microorganisms (BCCM ${ }^{\mathrm{TM}}$ ), Croix du Sud 3, bte 6, 1348 Louvain la-Neuve, Belgium

${ }^{8}$ Departamento de Bioquímica e Microbiologia, Centro de Estudos de Insetos Sociais, Universidade Estadual Paulista, Avenida 24A, 1515 Rio Claro, SP 13506-900, Brazil

${ }^{9}$ Centro de Recursos Microbiológicos (CREM), Biotechnology Unit, Faculdade de Ciências e Tecnologia, Universidade Nova de Lisboa, 2829-516 Caparica, Portugal

${ }^{10}$ Laboratório de Microbiologia Ambiental e Biologia, Campus Universitário de Palmas, Fundação Universidade Federal do Tocantins, Palmas, Tocantins 77010-154, Brazil
}

\begin{abstract}
Analyses of nucleotide sequences from the D1/D2 domains of the large-subunit rDNA and phenotypic characteristics showed that the genera Moniliella and Trichosporonoides are members of a single, monophyletic clade that would be best represented by a single anamorphic genus. On the basis of taxonomic priority, we propose the transfer of the five species of the genus Trichosporonoides to the genus Moniliella. The description of the genus Moniliella is emended and the following new combinations are proposed: Moniliella madida comb. nov., Moniliella megachiliensis comb. nov., Moniliella nigrescens comb. nov., Moniliella oedocephalis comb. nov. and Moniliella spathulata comb. nov. In addition, ten strains representing a novel yeast species belonging to the Moniliella clade were isolated from flowers in Thailand, Cuba and Brazil. Analysis of the internal transcribed spacer and D1/D2 large-subunit rDNA sequences indicated that the isolates represent a single species that was distinct from other species of the Moniliella clade. The name Moniliella fonsecae sp. nov. is proposed to accommodate these strains. The type strain is BCC $7726^{\top}\left(=\right.$ CBS $\left.10551^{\top}\right)$.
\end{abstract}

Abbreviations: ITS, internal transcribed spacer; LSU, large subunit. The GenBank/EMBL/DDBJ accession numbers for the sequences reported in this paper are DQ400366, AM947064, EF137915, EU252153 and EU545185.
The genus Moniliella was proposed by Stolk \& Dakin (1966) to accommodate two novel species, M. acetoabutens and M. tomentosa. Two other species, Moniliella suaveolens 
and Moniliella mellis, were described by von Arx (1972) and Rao \& de Hoog (1975), respectively. De Hoog \& Guého (1984) proposed the new combination Moniliella pollinis for M. tomentosa var. pollinis on the basis of slight ecological, morphological and physiological differences, supported by a marked difference in the DNA G $+\mathrm{C}$ content. In general, the four Moniliella species are associated with fatty substrates, honey, pollen, tobacco, human sputum or spoiled foods (de Hoog \& Smith, 1998a). The genus is similar to Trichosporonoides (Haskins \& Spencer, 1967) and the two were considered to be possibly synonymous by Boekhout (1998) and de Hoog \& Smith (1998a, b). The descriptions of the two genera were based on similar phenotypic characteristics. Species of both genera form smooth, velvety or cerebriform colonies, and most become olivaceous; pseudomycelium and arthroconidia are formed; sugars are fermented; nitrate is assimilated; the diazonium blue $\mathrm{B}$ reaction is positive; urease is produced; coenzyme Q-9 is produced; and xylose and fucose are absent from cell walls (de Hoog \& Smith, $1998 \mathrm{a}, \mathrm{b})$. The type species of the genus Moniliella is M. acetoabutens, and the type species of the genus Trichosporonoides is T. oedocephalis (de Hoog \& Smith, 1998a, b).

In the course of three independent studies of yeasts associated with plants in Thailand, Cuba and Brazil, several isolates of an unidentified yeast species were found. Analysis of sequences of the internal transcribed spacer (ITS) and D1/D2 domains of the large-subunit (LSU) rDNA showed that these strains represented a single species that was genetically distinct from other species in the Moniliella-Trichosporonoides clade. The name Moniliella fonsecae sp. nov. is proposed for the novel species, in honour of the Portuguese yeast researcher Álvaro Fonseca, in recognition of his contributions to yeast systematics and ecology. In addition, we propose the transfer of Trichosporonoides species to the genus Moniliella based on phenotypic characteristics and phylogenetic sequence analyses.
The origins of strains of the novel species studied are listed in Table 1. The strain from Thailand was isolated from an unidentified flower collected in Khao-Yai National Park, Nakhonratchasima Province, in November 2000. The strain from Cuba was collected in October 2005 from a flower of Angelonia pilosella (Scophulariaceae), province Pinar del Río, near the city Viñales. The Brazilian strains were isolated from flowers of Byrsonima orbigniana ('murici', Malpighiaceae) collected in a forest fragment (Ipuca) of the Lago Verde Estate, in the flooded plains of the Araguaia River, state of Tocantins, in June 2005. The nectary regions of flowers were scraped gently with a sterile loop and streak-inoculated onto YM agar (comprising: $1.0 \%$ glucose, $0.5 \%$ peptone, $0.3 \%$ malt extract, $0.3 \%$ yeast extract and $2.0 \%$ agar, w/v) containing $100 \mathrm{mg}$ chloramphenicol $l^{-1}$. The plates were incubated at room temperature $\left(25 \pm 3{ }^{\circ} \mathrm{C}\right)$ for $3-8$ days. Each different yeast morphotype was purified and maintained on YM slants or in liquid nitrogen storage for later identification. The yeasts were characterized by using standard methods (Yarrow, 1998). Identifications followed the taxonomic keys of Kurtzman \& Fell (1998).

The ITS/5.8S rDNA and the D1/D2 variable domains of the LSU rDNA were amplified directly from whole cells as described previously (Marinoni \& Lachance, 2004). The amplified DNA was cleaned on QIAquick PCR columns (Qiagen) and sequenced using an $\mathrm{ABI}$ sequencer at the John P. Robarts Research Institute, London, Ontario, Canada. The type strains of M. acetoabutens and M. mellis were also sequenced. The sequence was edited with the program DNAMAN, version 6 (Lynnon BioSoft). Existing sequences for other yeasts were retrieved from GenBank. The CLUSTAL W software (Thompson et al., 1994) incorporated in DNAMAN was used to align the sequences and construct a neighbour-joining tree with 1000 bootstrap iterations using the Kimura two-parameter transform.

Sequence comparisons indicated that the strains from Brazil, Cuba and Thailand represented a novel yeast species belonging to the Moniliella-Trichosporonoides clade (Fig. 1).

Table 1. List of isolates of Moniliella fonsecae sp. nov.

BCC, BIOTEC Culture Collection, Thailand; CBS, Centraalbureau voor Schimmelcultures, The Netherlands; UFMG, Culture Collection of Microorganisms and Cells of the Universidade Federal de Minas Gerais, Brazil; MUCL, Mycothèque de l'Université catholique de Louvain, Belgium; CRGF, Collection of Fungal Genetic Resources, Cuba.

\begin{tabular}{|c|c|c|}
\hline Strain number & Source & Locality \\
\hline BCC $7726^{\mathrm{T}}\left(=\mathrm{CBS} 10551^{\mathrm{T}}\right)$ & Unidentified flower & $\begin{array}{l}\text { Khao-Yai National Park, Nakhonratchasima } \\
\text { Province, Thailand }\end{array}$ \\
\hline MUCL $51004(=$ CRGF 832) & Flower of Angelonia pilosella (Scophulariaceae) & Province Pinar del Río, Cuba \\
\hline $\begin{array}{l}\text { UFMG-05-T37, UFMG-05-T39.1, UFMG-05- } \\
\text { T40.1, UFMG-05-T43.2, UFMG-05-T44 } \\
\text { (=CBS 10567), UFMG-05-T45.1, UFMG-05- } \\
\text { T46B, UFMG-05-T47.1 }\end{array}$ & Flowers of Byrsonima orbigniana & $\begin{array}{l}\text { Ipuca forest fragment, Lago Verde estate, } \\
\text { Tocantins, Brazil }\end{array}$ \\
\hline
\end{tabular}




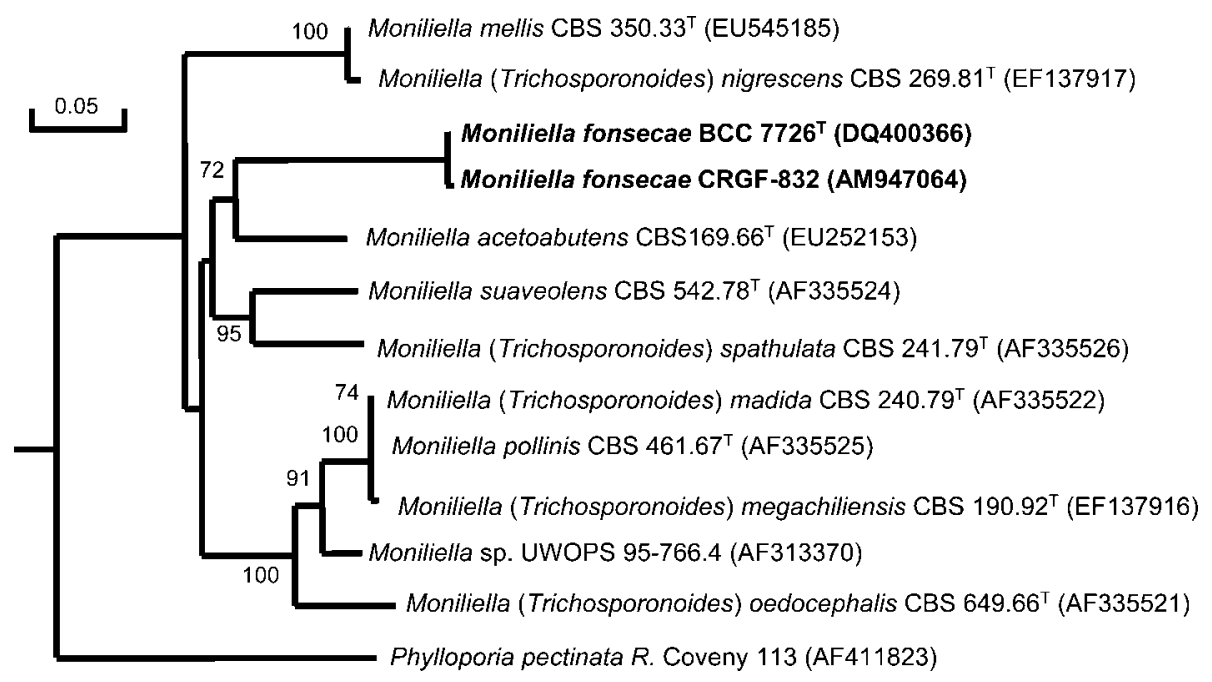

Fig. 1. Neighbour-joining phylogram based on the D1/D2 divergent domains of the LSU rDNA sequence of $M$. fonsecae sp. nov. and its closest relatives. Percentage bootstrap values were obtained from 1000 iterations. Bar, $5 \%$ sequence divergence.

The isolate from Thailand and the Brazilian strain UFMG-05-T44 had the same sequence in the ITS/5.8S and D1/D2 LSU rDNA. The Cuban strain had two substitutions in the D1/D2 LSU rDNA and two substitutions in the ITS region in comparison with the other two. The closest relatives of this novel species were $M$. acetoabutens, M. suaveolens and Trichosporonoides spathulata. The D1/D2 LSU rDNA sequence of the novel species differed by $15 \%$ or more (nearly 100 substitutions, depending on the alignment) from any related species, indicating a long history of divergent evolution. The phylogram in Fig. 1 further showed that the genera Moniliella and Trichosporonoides are members of a single, monophyletic clade that would be best represented by a single anamorphic genus, as suggested by Boekhout (1998), because of their similar phenotypic characteristics. The genus Moniliella was described in 1966 (Stolk \& Dakin, 1966) and has taxonomic priority over Trichosporonoides, which was described in 1967 (Haskins \& Spencer, 1967). On the basis of taxonomic priority, the name Moniliella fonsecae sp. nov. is proposed for the novel species isolated from flowers in Thailand, Cuba and Brazil.

The isolation of M. fonsecae sp. nov. in Thailand, Cuba and Brazil suggests that it is a widespread organism adapted to flowers of tropical forest ecosystems and to the insects that visit these flowers. $M$. fonsecae sp. nov. has a narrow physiological profile, assimilating only a few carbon sources. This suggests that the yeast is a habitat specialist, possibly restricted to sugary substrates such as nectar from tropical flowers.

The phylogenetic placement of the MoniliellaTrichosporonoides clade is not well established. The species included in the analysis in Fig. 1 represent all those for which D1/D2 LSU sequences are available in GenBank. The outgroup was the nearest neighbour detected in the database by using a BLAST search (Altschul et al., 1997). Phylloporia pectinata is a member of the Hymenochaetales, class Agaricomycetes in the Basidiomycetes (Wagner \& Ryvarden, 2002; Hibbett et al., 2007). Other sequences with a high similarity score would link the clade to the order Tilletiales. Hibbett et al. (2007) classified Tilletiales in the Ustilagionomycotina, class Exobadiomycetes. Furthermore, P. pectinata (outgroup; Fig. 1) exhibited $25 \%$ or more sequence divergence from any species in the tree, which is beyond the limit of useful resolution for the gene in question. A preliminary examination of the small-subunit rRNA gene of a clade member (M. A. Lachance, unpublished observations) did not result in a more reliable placement, due partly to the paucity of sequences for that gene in the database. Additional studies will be necessary to obtain a secure placement, although it is clear that the clade belongs to the Basidiomycetes.

On the basis of taxonomic priority, we suggest the transfer of the five Trichosporonoides species to the genus Moniliella. For this reason, we propose an emendation of the description of the genus Moniliella and the following new combinations.

Moniliella madida (de Hoog) Rosa \& Lachance comb. nov. Basionym: Trichosporonoides madida G. S. de Hoog. Stud Mycol 19 (1979), 25.

Moniliella megachiliensis (Inglis \& Sigler) Rosa \& Lachance comb. nov. Basionym: Trichosporonoides megachiliensis G. D. Inglis \& L. Sigler. Mycologia 84 (1992), 556.

Moniliella nigrescens (Hocking \& Pitt) Rosa \& Lachance comb. nov. Basionym: Trichosporonoides nigrescens A. D. Hocking \& J. I. Pitt. Antonie van Leeuwenhoek 47 (1981), 413. 
Moniliella oedocephalis (Haskins \& Spencer) Rosa \& Lachance comb. nov. Basionym: Trichosporonoides oedocephalis R. H. Haskins \& J. F. T. Spencer. Can J Bot 45 (1967), 519.

Moniliella spathulata (de Hoog) Rosa \& Lachance comb. nov. Basionym: Trichosporonoides spathulata G. S. de Hoog. Stud Mycol 19 (1979), 23.

With the assignment of the five species of the genus Trichosporonoides to the genus Moniliella and the description of the non-fermenting species $M$. fonsecae sp. nov., the genus description requires emendation.

\section{Emended description of Moniliella Stolk and Dakin emend. Rosa \& Lachance}

Colonies are smooth, velvety or cerebriform and creamcoloured or greyish to olivaceous. Budding is multilateral. Pseudomycelium, true hyphae and chlamydospores may be present. Cell walls are multilamellar. Septal dolipores are present. Sugars are fermented by most species. Nitrate is assimilated. Diazonium blue B reaction is positive. Urease is produced. Coenzyme Q-9 is produced. Xylose and fucose are absent from cell walls.

\section{Latin diagnosis of Moniliella fonsecae Rosa, Nakase, Jindamorakot, Limtong, Lachance, Fidalgo-Jiménez, Daniel, Pagnocca, Inácio \& Morais sp. nov.}

Cultura in agaro malti post dies $7\left(22^{\circ} \mathrm{C}\right)$ coloniae cerebriformae, cremae. Colour in medio carbonis fundamento cum sucrosum pulla et olivaceae. Cellulae ovoidae aut elongate, gemmantes $(2-4 \times 3-6 \mu \mathrm{m})$. In agaro farinae Zea mays post dies 14 pseudomycelium et mycelium verum formantur. Glucosum non fermentatur. Glucosum, sucrosum, cellobiosum, inulinum (variabile), ethanolum, glycerolum, erythritolum, xylitolum (variabile), acidum succinicum, acidum gluconicum (variabile) et hexadecanum assimilantur, et non galactosum, L-sorbosum, trehalosum, maltosum, melezitosum, raffinosum, melibiosum, lactosum, amylum solubile, D-xylosum, L-rhamnosum, L-arabinosum, D-arabinosum, D-ribosum, salicinum, ribitolum, galactitolum, mannitolum, glucitolum, acidum citricum, myo-inositolum, acidum lacticum, glucosaminum, $\mathrm{N}$-acetylglucosaminum, ethylacetas, methanolum, 2-propanolum nec acetonum. Ethylaminum (variabile), lysinum, cadaverinum, natrium nitricum et natrium nitrosum assimilantur. Ad crescentiam vitaminae externae non-necessariae. Augmentum in $37{ }^{\circ} \mathrm{C}$ (variabile). Habitat flores in Thailandia, Cuba et Brasil.

Typus BCC $7726^{\mathrm{T}}$. In collectione zymotica Centraalbureau voor Schimmelcultures, Trajectum ad Rhenum, sub no. CBS $10551^{\mathrm{T}}$ deposita est.

\section{Description of Moniliella fonsecae Rosa, Nakase, Jindamorakot, Limtong, Lachance, Fidalgo- Jiménez, Daniel, Pagnocca, Inácio \& Morais sp. nov.}

Moniliella fonsecae (fon.se' cae. L. gen. sing. m. adj. fonsecae of Fonseca, in honour of the Portuguese yeast researcher Álvaro Fonseca for his contributions to yeast systematics and ecology).

After 7 days on malt extract/yeast extract agar at $22{ }^{\circ} \mathrm{C}$, colonies are cerebriform, cream-coloured (Brazilian strains become olivaceous-brown on yeast nitrogen base plus sucrose), soft, wrinkled and sometimes dry. Cells are ovoid to elongate and multiply by multilateral budding $(2-4 \times 3-$ $6 \mu \mathrm{m}$ ) (Fig. 2). A pellicle is formed after 3 days on fermentation medium. In Dalmau plates after 2 weeks on cornmeal agar, abundant pseudohyphae, true mycelia and arthroconidia are formed. Glucose is not fermented. Glucose, sucrose, cellobiose, inulin (variable), ethanol, glycerol, erythritol, xylitol (variable), succinic acid, gluconic acid (variable) and hexadecane are assimilated. No growth occurs on galactose, L-sorbose, maltose, trehalose, lactose, melibiose, melezitose, raffinose, soluble starch, Dxylose, L-rhamnose, L-arabinose, D-arabinose, D-ribose, galactitol, mannitol, glucitol, salicin, ribitol, lactic acid, citric acid, myo-inositol, methanol, D-glucosamine, $\mathrm{N}$ acetyl-D-glucosamine, 2-propanol, ethyl acetate or acetone. Assimilation of nitrogen compounds: positive for nitrate, nitrite, lysine, ethylamine- $\mathrm{HCl}$ (variable) and cadaverine. Growth in vitamin-free medium is positive. Growth in amino-acid-free medium is positive. Growth at $37{ }^{\circ} \mathrm{C}$ is

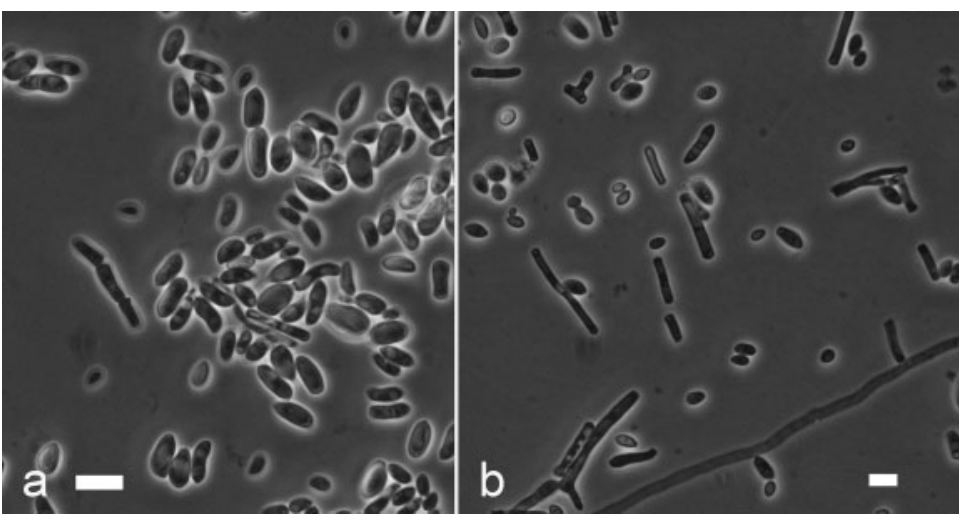

Fig. 2. Phase-contrast micrographs of cells of M. fonsecae sp. nov. after 2 days on yeast extract-malt extract agar at $22^{\circ} \mathrm{C}$. (a) Strain BCC $7726^{\top}$ : budding cells and arthroconidia; (b) strain UFMG-05-T44: budding cells, arthroconidia and true hyphae. Bars, $5 \mu \mathrm{m}$. 
variable. Growth on YM agar with $10 \%$ sodium chloride is negative. Growth in $50 \%$ glucose/yeast extract $(0.5 \%)$ is variable. Starch-like compounds are not produced. In $100 \mu \mathrm{g}$ cycloheximide $\mathrm{ml}^{-1}$ growth is negative. Urease activity is positive. Diazonium Blue B reaction is positive.

The habitat is flowers in tropical forest ecosystems in Thailand, Cuba and Brazil.

The type strain is BCC $7726^{\mathrm{T}}$ (sequences of the ITS/5.8S and D1/D2 regions of the rDNA were deposited in GenBank under accession numbers EF137915 and DQ400366, respectively), recovered from an unidentified flower in Thailand. The strain from Thailand and one strain from Brazil have been deposited in the collection of the Yeast Division of the Centraalbureau voor Schimmelcultures, Utrecht, The Netherlands, as strains CBS $10551^{\mathrm{T}}$ and CBS 10567, respectively.

\section{Acknowledgements}

This work was funded by Programa Norte de Pesquisas e PósGraduação do Conselho Nacional de Desenvolvimento Científico e Tecnológico of Brazil (PNOPG-CNPq), CNPq - Brazil, Fundação do Amparo a Pesquisa do Estado de Minas Gerais (FAPEMIG-Brazil, process no. CBB - 378/04), the Natural Science and Engineering Research Council of Canada (M.-A.L.), and the Conseil InterUniversitaire de la Communauté Française de Belgique: Commission Universitaire pour le Développement (CIUF-CUD-MUCL-Cuba), the Belgian Federal Science Policy (BCCM C2/10/007 and BCCM C3/10/ 003) and the European Commission Marie Curie Mobility Actions (MIRG-CT-2005-016539). A. Fidalgo-Jiménez thanks the Cuban Ministry of Science, Technology and Environment for providing facilities and financial support as well as R. Oviedo, I. Ventosa and I. Fuentes for their assistance with the plant identifications. We would like to thank to Drs Vincent Robert and Marizeth Groenewald from Centraalbureau voor Schimmelcultures for sending us the type strains of $M$. acetoabutens and M. mellis.

\section{References}

Altschul, S. F., Madden, T. L., Schaffer, A. A., Zhang, J. H., Zhang, Z., Miller, W. \& Lipman, D. J. (1997). Gapped BLAST and PSI-BLAST: a new generation of protein database search programs. Nucleic Acids Res 25, 3389-3402.

Boekhout, T. (1998). Diagnostic descriptions and key to presently accepted heterobasidiomycetous genera. In The Yeasts, a Taxonomic Study, 4th edn, pp. 627-634. Edited by C. P. Kurtzman \& J. W. Fell. Amsterdam: Elsevier.

de Hoog, G. S. \& Guého, E. (1984). Deoxyribonucleic acid base composition and taxonomy of Moniliella and allied genera. Antonie van Leeuwenhoek 50, 135-141.

de Hoog, G. S. \& Smith, M. T. (1998a). Moniliella Stolk \& Dakin. In The Yeasts, a Taxonomic Study, 4th edn, pp. 785-788. Edited by C. P. Kurtzman \& J. W. Fell. Amsterdam: Elsevier.

de Hoog, G. S. \& Smith, M. T. (1998b). Trichosporonoides Haskins \& Spencer. In The Yeasts, a Taxonomic Study, 4th edn, pp. 873-877. Edited by C. P. Kurtzman \& J. W. Fell. Amsterdam: Elsevier.

Haskins, R. H. \& Spencer, J. F. T. (1967). Trichosporonoides oedocephalis n. gen., n. sp. I. Morphology, development, and taxonomy. Can J Bot 45, 515-520.

Hibbett, D. S., Binder, M., Bischoff, J. F., Blackwell, M., Cannon, P. F., Eriksson, O. E., Huhndorf, S., James, T., Kirk, P. M. \& other authors (2007). A higher-level phylogenetic classification of the Fungi. Mycol Res 111, 509-547.

Kurtzman, C. P. \& Fell, J. W. (1998). The Yeasts, a Taxonomic Study. Amsterdam: Elsevier.

Marinoni, G. \& Lachance, M. A. (2004). Speciation in the large-spored Metschnikowia clade and establishment of a new species, Metschnikowia borealis comb. nov. FEMS Yeast Res 4, 587-596.

Rao, V. \& de Hoog, G. S. (1975). Some notes on Torula. Persconia 8 , 199-206.

Stolk, A. C. \& Dakin, J. C. (1966). Moniliella, a new genus of Moniliales. Antonie van Leeuwenhoek 32, 399-406.

Thompson, J. D., Higgins, D. G. \& Gibson, T. J. (1994). CLUSTAL W: improving the sensitivity of progressive multiple sequence alignment throught sequence weighting, position-specific gap penalties and weight matrix choice. Nucleic Acids Res 22, 4673-4680.

von Arx, J. A. (1972). On Endomyces, Endomycopsis and related yeastlike fungi. Antonie van Leeuwenhoek 38, 289-309.

Wagner, T. \& Ryvarden, L. (2002). Phylogeny and taxonomy of the genus Phylloporia (Hymenochaetales). Mycol Prog 1, 105-116.

Yarrow, D. (1998). Methods for the isolation and identification of yeasts. In The Yeasts, a Taxonomic Study, 4th edn, pp. 77-100. Edited by C. P. Kurtzman \& J. W. Fell. Amsterdam: Elsevier. 